\author{
PRIMARY: JURNAL PENDIDIKAN GURU SEKOLAH DASAR \\ VOLUME 10 NOMOR 5 OKTOBER 2021 \\ ISSN : 2303-1514 | E-ISSN : 2598-5949 \\ DOI : http://dx.doi.org/10.33578/jpfkip.v10i5.8340 \\ https://primary.ejournal.unri.ac.id/index.php/JPFKIP
}

\title{
IMPROVING SPEAKING SKILLS AND CURIOSITY CHARACTERS THROUGH THE TALKING STICK LEARNING MODEL
}

\author{
Kostansa Yopo ${ }^{1}$, Agus Kichi Hermansyah ${ }^{2}$, Dewi Puji Rahayu ${ }^{3}$ \\ 1,2,3 Pendidikan Guru Sekolah Dasar, Universitas Musamus, Merauke, Indonesia \\ 1aguskichi@unmus.ac.id; ${ }^{2}$ kostansa1997yopo@gmail.com; ${ }^{3}$ rahayu@unmus.ac.id
}

\section{MENINGKATKAN KETERAMPILAN BERBICARA DAN KARAKTER RASA INGIN TAHU MELALUI MODEL PEMBELAJARAN TALKING STICK}

\begin{tabular}{|c|c|}
\hline ARTICLE HISTORY & ABSTRACT \\
\hline $\begin{array}{l}\text { Submitted: } \\
11 \text { Juni } 2021 \\
11^{\text {th }} \text { June } 2021\end{array}$ & $\begin{array}{l}\text { Abstract: This study aimed to improve speaking skills and curiosity characters through the } \\
\text { Talking Stick learning model. This research was classroom action research with Kurt Lewin's } \\
\text { model. This research consisted of four stages in each cycle; planning, implementing, observing, } \\
\text { and reflecting. This research was conducted at SD YPPK St. Agustinus Erambu. The research } \\
\text { subjects were } 12 \text { students at grade IV (eight boys and four girls). Data collection techniques } \\
\text { used were observation and tests. The research instruments were the syllabus, lesson plans, } \\
\text { student worksheets, and tests. The data analysis techniques were class averages, classical } \\
\text { learning completeness, student and teacher activity data analysis. The results obtained an } \\
\text { increase in students' speaking skills and curiosity character, as well as the minimum } \\
\text { completeness criteria. The result of the average score in the first cycle for speaking skills was } \\
67.91 \text { while the curiosity character was } 72 \text { and in the second cycle, the speaking skills was } \\
72.25 \% \text { while the curiosity character was } 86 \% \text {. It means that the Talking Stick learning model } \\
\text { improved students'speaking skills and curiosity character. }\end{array}$ \\
\hline & Keywords: speaking skills, curiosity character \\
\hline
\end{tabular}

Accepted:

08 Oktober 2021

08 ${ }^{\text {th }}$ October 2021

Published:

28 Oktober 2021

$28^{\text {th }}$ October 2021

Abstrak: Tujuan penelitian ini meningkatkan keterampilan berbicara dan karakter rasa ingin tahu melalui model pembelajaran Talking Stick. Penelitian ini yakni penelitian tindakan kelas, terdiri dari empat tahap dalam setiap siklus yaitu perencanaan, pelaksanaan, pengamatan, dan refleksi. Penelitian ini dilaksanakan di SD YPPK St. Agustinus Erambu. Subjek penelitian adalah siswa kelas IV berjumlah 12 siswa (8 laki-laki dan 4 perempuan). Teknik pengumpulan data meliputi observasi dan tes. Instrumen penelitian memakai silabus, RPP, lembar kerja siswa dan evaluasi akhir siklus. Tenik analisis data dalam penelitian ini adalah rata-rata kelas, ketuntasan belajar klasikal, dan analisis data aktivitas siswa serta guru. Hasil yang didapat adalah adanya peningkatan keterampilan berbicara dan karakter rasa ingin tahu siswa, dan kriteria ketuntasan minimal. Dari hasil nilai rata-rata kelas siklus I keterampilan berbicara sebesar $67.91 \%$ sedangkan karakter rasa ingin tahu sebesar $72 \%$ dan siklus II keterampilan berbicara sebesar $72.25 \%$ sedangkan karakter rasa ingin tahu $86 \%$. Berdasarkan hasil penelitian, disimpulkan bahwa penggunaan model pembelajaran Talking Stick dapat meningkatkan keterampilan berbicara dan karakter rasa ingin tahu siswa.

Kata Kunci: keterampilan berbicara, karakter rasa ingin tahu

\section{CITATION}

Yopo, K., Hermansyah, A. K., \& Rahayu, D. P. (2021). Improving Speaking Skills and Curiosity Characters through the Talking Stick Learning Model. Primary: Jurnal Pendidikan Guru Sekolah Dasar, $10 \quad$ (5), 1271-1278. DOI: http://dx.doi.org/10.33578/jpfkip.v10i5.8340.

\section{PENDAHULUAN}

Pendidikan di sekolah dasar merupakan jenjang pendidikan dasar yang berfungsi sebagai peletakan dasar-dasar keilmuan, dan membantu mengoptimalkan perkembangan anak melalui pembelajaran yang dibimbing oleh guru (Susanto, 2016). Upaya peningkatan kualitas pendidikan dapat 
tercapai secara optimal, apabila dilakukan pengembangan dan perbaikan terhadap komponen pendidikan yang meliputi pendidik, anak didik dan proses pembelajaran (Hurit \& Harmawati, 2019). Sebagai pendidik, seorang guru dituntut memiliki profesionalisme di dalam pendidikan. Selain guru, anak didik juga mempengaruhi hasil belajar anak itu sendiri (Rahayu, 2019). Jadi, untuk meningkatkan hasil belajar anak didik seorang guru harus melaksanakan pembelajaran yang menyenangkan sehingga dapat memotivasi anak didik untuk memperoleh hasil belajar yang sesuai dengan tujuan pembelajaran (Hermansyah, 2016).

Pendidik atau guru adalah faktor yang sangat penting dalam pendidikan, termasuk di dalamnya yakni pendidikan karakter. Pendidikan karakter dapat diartikan sebagai usaha untuk memahami, membentuk, memupuk nilai-nilai etika, baik untuk diri sendiri maupun untuk semua warga masyarakat atau warga negara secara keseluruhan (Hermansyah, Suyono, \& Hasanah, 2017). Zainudin dalam bukunya telah menyimpulkan bahwa pendidikan karakter dapat mempengaruhi akhlak mulia peserta didik (Zainudin, 2012). Selain pendidikan karakter, karakter rasa ingin tahu juga menjadi penting untuk dikembangkan oleh guru kepada siswa. Pentingnya keterampilan berbicara dalam komunikasi bahwa apabila seseorang memiliki keterampilan berbicara yang baik, dia akan memperoleh keuntungan sosial maupun profesional (Astiar, Satianingsih, \& Yustitia, 2020; Ghazali, 2013). Pentingnya mengapa rasa ingin tahu ini perlu dikembangkan dalam diri peserta didik antara lain yaitu rasa ingin tahu membuat pikiran peserta didik menjadi aktif (Kurniawan, 2016; Setiawan \& Tumardi, 2019). Rasa ingin tahu membuat peserta didik menjadi para pengamat yang aktif. Rasa ingin tahu akan membuka dunia-dunia baru yang menantang dan menarik peserta didik untuk mempelajari lebih dalam.

Berdasarkan hasil wawancara dengan guru kelas IV mengenai pelaksanaan pada hari kamis tanggal 30 Juli 2020. Pembelajaran khususnya di kelas IV SD YPPK St. Agustinus Erambu, masih ditemukan beberapa masalah antara lain: siswa kurang aktif dalam menerima pembelajaran saat guru melaksanakan proses pembelajaran, siswa cenderung diam dan karakter rasa ingin tahu siswa yang belum muncul atau tidak kelihatan dan tidak menunjukan keingintahuan mereka dalam menerima pembelajaran. Selain itu, keterbatasan siswa dalam memahami materi pembelajaran membuat guru harus bekerja lebih dalam mendidik dan mengelola kelas dengan baik. Hal ini menyebabkan alokasi waktu yang dicapai dalam 2 pertemuan, seringkali memerlukan waktu 3 hingga 4 kali pertemuan. Masalah-masalah seperti ini yang masih sering ditemukan dalam pembelajaran di kelas. Kenyataan menunjukan bahwa keterampilan berbicara belum optimal dikuasai oleh siswa. Oleh karena itu para guru hendaknya mencari dan menerapkan model yang tepat dalam membelajarkan keterampilan berbicara guna meningkatkan hasil pembelajaran.

Pengaruh dalam proses pembelajaran dituntut untuk memberikan motivasi pada siswa untuk aktif dalam proses pembelajaran (Yunarni \& Harsiwi, 2018). Pembelajaran harus memiliki model, strategi metode dan media yang bervariasi untuk menumbuhkan keterampilan berbicara siswa (Sumarsono, Syamsudin, Hermansyah, \& Iswahyuni, 2018). Salah satu model pembelajaran yang dapat menumbuhkan keterampilan berbicara pada siswa adalah model Talking Stick (Mahliza, 2013). Model pembelajaran Talking Stick dapat digunakan untuk meningkatkan keterampilan berbicara. Menurut Sudrajat, permainan dengan menggunakan model Talking Stick supaya saat bergiliran berbicara siswa lebih siap, tidak banyak waktu terbuang dan saling tunjuk karena sudah ada aturan bermain. Sehingga pembelajaran dengan menggunakan model Talking Stick dapat mendorong siswa untuk berani mengungkapkan pendapat dalam berbicara 
(Sudrajat, 2008).

Penelitian ini dapat terlaksana setelah peneliti mempelajari penelitian terdahulu yakni sebagai berikut. Pertama, Eka Ratnawati, Penelitian dengan judul "Peningkatan Keterampilan Berbicara melalui Dongeng dalam Pembelajaran Bahasa Indonesia Siswa Kelas I Sekolah Dasar Negeri Bendosari Kecamatan Sawit Kabupaten Boyolali” (Ratnawati, 2010). Kesimpulan dalam penelitian ini adalah terjadinya peningkatan kemampuan berbicara siswa I SD Negari 2 Bendosari setelah dilaksanakan pembelajaran dengan mengunakan dongeng. Dilihat dari tes kemampuan berbicara pada siklus I diketahui 18 dari 30 siswa telah mencapai KKM (60), dan meningkat pada siklus II dimana 29 dari 30 siswa telah berhasil mancapai KKM (60).

Kedua, Penelitian oleh Sukatmi, "Upaya Peningkatan Keterampilan Berbicara dengan Media Gambar" penelitian ini merupakan penelitian tindakan kelas pada siswa kelas V SDN 11 Nambangan, selogiri, kabupaten Wonogiri" (Sukatmi, 2009). Hasil penelitian menyimpulkan bahwa penerapan media gambar dapat meningkatkan keterampilan berbicara siswa. Hal ini terlihat pada kemampuan siswa berkomunikasi secara lisan dengan lancar, dan lebih berani berbicara dengan bahasa yang komunikatif, nilai keterampilan berbicara siswa meningkat setelah menerapkan media gambar dapat meningkatkan keterampilan berbicara siswa. meningkat setelah penerapan media gambar, terlihat dari penelitian langsung 31 siswa, $85 \%$
(26 siswa) telah mencapai KKM (68). Adapun permasalahan dan perbedaan penelitian terdahulu yakni dalam penelitian ini diutamakan pada penggunaan model talking stick untuk meningkatkan keterampilan berbicara dan karakter rasa ingin tahu.

\section{METODE PENELITIAN}

Jenis Penelitian Ini adalah penelitian Tindakan Kelas (PTK) yakni penelitian yang memiliki siklus yang dilakukan guru untuk mengatasi permasalahan di kelas (Arikunto, 2014). Subjek penelitian ini adalah 1 orang guru kelas IV dan 12 siswa, yang terdiri dari 8 siswa laki-laki dan 4 siswa perempuan di Kelas IV SD YPPK Santo Agustinus Erambu. Penelitian tindakan kelas ini dilaksanakan dua siklus, setiap siklus dilaksanakan sebanyak 3 kali pertemuan dengan alokasi waktu 2 x 35 menit dalam 1 pertemuan. Siklis I, pada pertemuan pertama dilaksanakan Senin 03 Agustus 2020, pertemuan kedua dilaksananakn Selasa 04 Agustus 2020 dan, pertemuan ketiga dilaksanakan Rabu 05 Agustus 2020. Sedangkan pada siklus II, Pada pertemuan pertama dilaksanakan Senin 10 Agustus 2020, pertemuan kedua dilaksananakan Selasa 11 Agustus 2020 dan, pertemuan ketiga dilaksanakan Rabu 12 Agustus 2020. Dalam pelaksanaan setiap siklusnya pertemuan peratama dan kedua dilaksanakan proses pembelajaran sedangkan pertemuan ke 3 diberikan tes evaluasi secara lisan diakhir siklus. Prosedur penelitian dapat dilihat pada Gambar 1. 


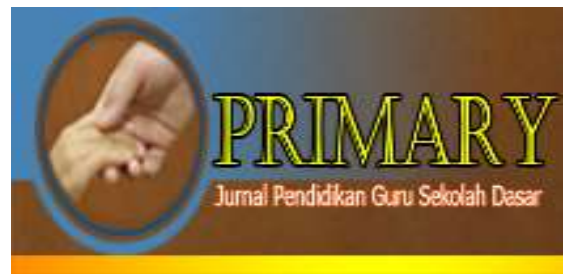

\section{PRIMARY: JURNAL PENDIDIKAN GURU SEKOLAH DASAR VOLUME 10 NOMOR 5 OKTOBER 2021}

ISSN : 2303-1514 | E-ISSN : 2598-5949

DOI : http://dx.doi.org/10.33578/jpfkip.v10i5.8340 https://primary.ejournal.unri.ac.id/index.php/JPFKIP

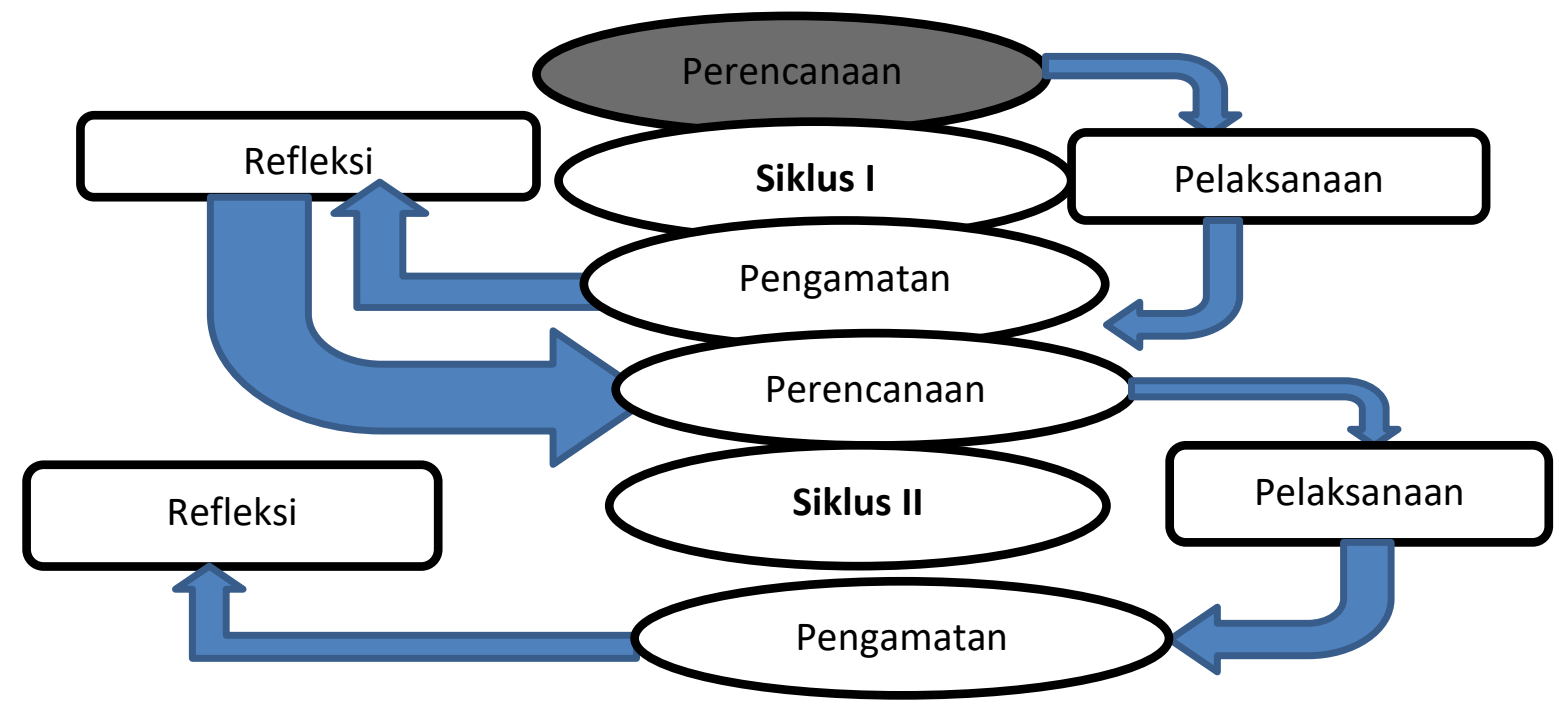

Gambar 1. Siklus Penelitian Tindakan Kelas (Arikunto, Suhardjono, 2014)

Teknik dan instrumen pengumpulan data yaitu wawancara, observasi, dan dokumentasi. Menurut (Sanjaya, 2012), analisis data adalah suatu proses mengolah dan menginterpretasikan data dengan tujuan untuk mendudukan berbagai informasi dan fungsinya hingga memiliki makna dan arti yang jelas sesuai tujuan penelitian. Analisis data penelitian tindakan kelas berupa deskriptif kualitatif dan deskriptif kuantitatif.

\section{Analisa Data Keterampilan Berbicara}

Analisis data keterampilan berbicara dan karakter rasa ingin tahu siswa terhadap pembelajaran menggunakan model Talking Stick. Kriteria skor penilaian keterampilan berbicara dapat dilihat pada Tabel 1 berikut.

\section{Tabel 1. Kriteria Skor Penilaian Keterampilan Berbicara}

\begin{tabular}{cc}
\hline Rentang persentase & Tingkat Ketercapaian Indikator \\
\hline $81 \%-100 \%$ & Sangat baik \\
$61 \%-80 \%$ & Baik \\
$41 \%-60 \%$ & Sedang \\
$21 \%-40 \%$ & Kurang \\
\hline
\end{tabular}

Nilai hasil belajar siswa secara individual menggunakan rumus sebagai berikut

(Purwanto, 2009: 112):

$$
\text { Nilai }=\frac{\text { Skor yang diperoleh }}{\text { Skor maksimun }} \times 100
$$

1) Nilai Rata-rata

Serta untuk menghitung nilai rata-rata siswa menggunakan rumus sebagai berikut:

$$
\mathrm{X}=\frac{\sum x}{N}
$$

Keterangan:

$\mathrm{X}=$ Nilai rata-rata $\sum x=$ Jumlah keseluruhan nilai yang diperoleh siswa

$\sum N=$ banyaknya data (siswa)

( Suharsini Arikunto, 2007: 284-285)

2) Ketuntasan Klasikal

Persentase ketuntasan belajar siswa secara klasikal dengan rumus sebagai berikut (Purwanto, 2009: 112):

Ketuntasan $=\frac{\sum s}{N} \times 100 \%$

Keterangan:

$\sum \mathrm{s}=$ Jumlah nilai siswa 
$\mathrm{N}=$ Banyak siswa

\section{HASIL DAN PEMBAHASAN}

Masing-masing Penelitian tindakan kelas ini dilakukan sebanyak dua (2) siklus dengan siklus terdiri atas tiga (3) pertemuan. Setelah pelaksanaan tindakan siklus I dan siklus II dengan menggunakan model talking stick, hasil penelitian menunjukkan terdapat peningkatan hasil belajar, peningkatan aktifitas siswa, dan peningkatan aktifitas guru. Keterampilan berbicara dan karakter rasa ingin tahu siswa siswa SD YPPK Santo Agustinus Erambu menggunakan model talking stickmengalami peningkatan yang baik.

\section{Siklus I}

Hasil pencapaian siswa setelah dilakukan tindakan siklus I mengalami peningkatan. Siswa kelas IV SD YPPK Santo Agustinus Erambu yang mencapai ketuntasan sebanyak 11 siswa (75\%), sedangkan siswa yang belum mencapai ketuntasan berjumlah 1 siswa $(25 \%)$. Hambatan yang di alami pada siklus I adalah: (1) siswa masih takut atau malu untuk bertanya; (2) siswa belum percaya diri untuk aktif di depan kelas; (3) Pada saat pelaksanaan tes evaluasi terdapat siswa yang tidak percaya diri dengan jawabannya sehingga menjiplak/meniru jawaban temannya.

Dengan melihat hal tersebut, peneliti kemudian menyusun rencana perbaikan yang dilaksanakan pada siklus II. Rencana perbaikannya adalah: (1) guru memotivasi siswa untuk tidak malu atau tidak takut untuk bertanya; (2) melakukan pendekatan pada siswa agar percaya diri untuk aktif; (3) memberi penguatan terhadap siswa agar mengerjakan soal evaluasinya dengan percaya diri; (4) guru lebih teliti dalam memantau kegiatan siswa terutama saat pelaksanaan evaluasi untuk memperoleh hasil yang benarbenar dari jawaban siswa itu sendiri tanpa melihat jawaban teman.

Siklus II

Berdasarkan hasil refleksi siklus I, peneliti mempersiapkan rencana pelaksanaan pembelajaran (RPP), LKS, dan Lembar Tes Evaluasi. Kemajuan hasil belajar siswa dilakukan tindakan siklus II. Siswa kelas IV SD YPPK St. Agustinus Erambu yang mencapai tingkat ketuntasan meningkat dari 9 siswa (75\%) pada siklus I menjadi 11 siswa (91.67\%), pada siklus II. Sedangkan siswa yang belum mencapai ketuntasan menurun dari 16 siswa $(8,33 \%)$ pada siklus I menjadi 3 siswa $(66.67 \%)$ pada siklus II.

Meskipun masih 1 siswa yang belum mencapai ketuntasan sesuai dengan KKM, tingkat kemajuan yang banyak yang di alami oleh siswa lainnya memberikan keyakinan bahwa dengan menggunakan model Talking Stickmeningkatkan keterampilan berbicara dan karakter rasa ingin tahu siswa Kelas IVB SD YPPK Santo Agustinus Erambu. Hasil penelitian menunjukkan aktifitas siswa dalam pembelajaran selama siklus I sampai dengan siklus II mengalami peningkatan. Pada siklus I berjumlah 9 siswa (75\%) menjadi 1 siswa (91.67\%) pada siklus II. Sedangkan aktifitas guru dalam pembelajaran selama tindakan siklus I dan siklus II meningkat, pada siklus I (91.07\%) meningkat menjadi $(96.42 \%)$ pada siklus II terdapat dalam kategori "Sangat Baik atau Sangat Aktif". Hal tersebut menunjukkan bahwa, menggunakan model Talking Stick dapat meningkatkan keterampilan berbicara siswa dan karakter rasa ingin tahu, aktifitas belajar siswa dan guru.

Dari refleksi yang dilakukan oleh peneliti, pelaksanaan pembelajaran keterampilan berbicara dan karakter rasa ingin tahu siswa manfaatnya dalam kehidupan sehari-hari menggunakan model Talking Stick sudah sesuai harapan. Hasil penelitian menunjukkan bahwa siswa dan guru dalam pelaksanaan pembelajaran meningkat. Hasil penelitian ini sejalan dengan penelitian relevan oleh Miftahul (2015) yaitu model ini mampu menguji kesiapan siswa, melatih keterampilan mereka dalam membaca dan memahami materi pembelajaran dengan cepat dan mengajak peserta didik untuk terus siap dalam situasi apapun. 
Penelitian ini berhubungan dengan penelitian (Kurniasih \& Sani, 2015) dari penelitian tersebut dapat disimpulkan bahwa, model belajar yang menarik dapat meningkatkan keterampilan berbicara dan karakter rasa ingin tahu siswa. Sehingga guru harus menginovasikan pembelajaran agar siswa semangat belajar. Dari uraian di atas penulis menyimpulkan bahwa menggunakan model Talking Stick dapat meningkatkan keterampilan berbicara dan karakter rasa ingin tahu peningkatan tersebut dapat dilihat dari 12 siswa 11 siswa tela mencapai nilai KKM di kelas IV SD YPPK Santo Agustinus Erambu tahun ajaran 2020/2021. Hal tersebut didukung oleh Hasil pencapaian siswa setelah dilakukan tindakan siklus I mengalami peningkatan. Siswa kelas IV SD YPPK Santo Agustinus Erambu yang mencapai ketuntasan sebanyak 11 siswa (75\%), sedangkan siswa yang belum mencapai ketuntasan berjumlah 1 siswa (25\%). Hambatan yang di alami pada siklus I adalah: 1) siswa masih takut atau malu untuk bertanya; 2) siswa belum percaya diri untuk aktif di depan kelas; 3) Pada saat pelaksanaan tes evaluasi terdapat siswa yang tidak percaya diri dengan jawabannya sehingga menjiplak/ meniru jawaban temannya.

Dengan melihat hal tersebut, peneliti kemudian menyusun rencana perbaikan yang dilaksanakan pada siklus II. Rencana perbaikannya adalah: 1) guru memotivasi siswa untuk tidak malu atau tidak takut untuk bertanya; 2) melakukan pendekatan pada siswa agar percaya diri untuk aktif; 3) memberi penguatan terhadap siswa agar mengerjakan soal evaluasinya dengan percaya diri; 4) guru lebih teliti dalam memantau kegiatan siswa terutama saat pelaksanaan evaluasi untuk memperoleh hasil yang benar-benar dari jawaban siswa itu sendiri tanpa melihat jawaban teman. Berdasarkan hasil refleksi siklus I, peneliti mempersiapkan rencana pelaksanaan pembelajaran (RPP), LKS, dan Lembar Tes Evaluasi. Kemajuan hasil belajar siswa dilakukan tindakan siklus II. Siswa kelas IV SD YPPK St. Agustinus Erambu yang mencapai tingkat ketuntasan meningkat dari 9 siswa $(75 \%)$ pada siklus I menjadi 11 siswa (91.67\%), pada siklus II. Sedangkan siswa yang belum mencapai ketuntasan menurun dari 16 siswa $(8.33 \%)$ pada siklus I menjadi 3 siswa (66.67\%) pada siklus II.

Meskipun masih 1 siswa yang belum mencapai ketuntasan sesuai dengan KKM, tingkat kemajuan yang banyak yang di alami oleh siswa lainnya memberikan keyakinan bahwa dengan menggunakan model talking stick meningkatkan keterampilan berbicara dan karakter rasa ingin tahu siswa Kelas IVB SD YPPK Santo Agustinus Erambu. Hasil penelitian menunjukkan aktifitas siswa dalam pembelajaran selama siklus I sampai dengan siklus II mengalami peningkatan. Pada siklus I berjumlah 9 siswa (75\%) menjadi 1 siswa (91.67\%) pada siklus II. Sedangkan aktifitas guru dalam pembelajaran selama tindakan siklus I dan siklus II meningkat, pada siklus I (91.07\%) meningkat menjadi (96.42\%) pada siklus II terdapat dalam kategori "Sangat Baik atau Sangat Aktif'. Hal tersebut menunjukkan bahwa, menggunakan model talking stick dapat meningkatkan keterampilan berbicara siswa dan karakter rasa ingin tahu, aktifitas belajar siswa dan guru.

Dari observasi dan refleksi yang dilakukan oleh peneliti, pelaksanaan pembelajaran keterampilan berbicara dan karakter rasa ingin tahu siswa manfaatnya dalam kehidupan sehari-hari menggunakan model talking stick sudah sesuai harapan. Hasil penelitian menunjukkan bahwa siswa dan guru dalam pelaksanaan pembelajaran meningkat. Hasil penelitian ini sejalan dengan penelitian relevan oleh Miftahul (2015) yaitu model ini mampu menguji kesiapan siswa, melatih keterampilan mereka dalam membaca dan memahami materi pembelajaran dengan cepat dan mengajak peserta didik untuk terus siap dalam situasi apapun.

Penelitian ini berhubungan dengan penelitian Kurniasih \& sani (2016). Dari kedua penelitian tersebut dapat disimpulkan bahwa, model belajar yang menarik dapat 
meningkatkan keterampilan berbicara dan karakter rasa ingin tahu siswa. Sehingga guru harus menginovasikan pembelajaran agar siswa semangat belajar. Dari uraian di atas penulis menyimpulkan bahwa menggunakan model talking stick dapat meningkatkan keterampilan berbicara dan karakter rasa ingin tahu siswa kelas IV SD YPPK Santo Agustinus Erambu tahun ajaran 2020/2021.

\section{SIMPULAN DAN REKOMENDASI}

Penelitian tindakan kelas pada siswa kelas IV SD YPPK St. Agustinus Erambu tahun ajaran 2020/2021 dilaksanakan dalam dua siklus. Berdasarkan pembahasan dan hasil penelitian maka dapat disimpulkan bahwa pembelajaran menggunakan model Talking Stick dapat meningkatkan keterampilan berbicara dan karakter rasa ingin tahu siswa kelas IV SD YPPK St. Agustinus Erambu. Di mana dapat dilihat dari hasil nilai rata-rata kelas siklus I sebesar 67.91 dan siklus II 76.25. Presentase klasikal pada siklus I sebesar $75 \%$ dan siklus II 91.67\%. Dari siklus I ke siklus II terdapat peningkatan sebesar $16.67 \%$. Pada siklus I yang mencapai kriteria ketuntasan minimal 9 siswa dari 12 siswa. Sedangkan pada siklus II yang telah mencapai kriteria ketuntasan minimal ada 11 siswa dari 12 siswa.Data tersebut di dapat dengan menggunakan lembar tes siklus I dan II. Sedangkan aktifitas guru sebesar $91.07 \%$ pada siklus I dan pada siklus II menjadi $96.42 \%$ dengan kriteria Sangat Baik. Hasil tersebut didapat dengan menggunakan lembar observasi kegiatan guru dalam proses pembelajaran.

\section{Rekomendasi}

Berdasarkan hasil penelitian yang telah dilaksanakan di SD YPPK St. Agustinus Erambu ada beberapa saran yang peneliti dapat disampaikan sebagai berikut:

1. Bagi siswa, hendaknya siswa mampu meningkatkan keterampilan berbicara dan karakter rasa ingin tahu siswa untuk diterapkan dalam kehidupan sehari-hari.
2. Bagi guru, agar dapat menggunakan model pembelajaran bervariasi sehingga menarik minat belajar siswa

3. Bagi sekolah, hendaknya penyediaan berbagai sarana dan prasarana yang menunjang pembelajaran.

4. Bagi peneliti lain, sebagai bahan referensi penelitian selanjutnya di kelas dengan model pembelajaran yang berbeda.

\section{DAFTAR PUSTAKA}

Arikunto., \& Suhardjono, S. (2014). Penelitian Tindakan Kelas. Jakarta: PT Bumi Aksara.

Astiar, F. A., Satianingsih, R., \& Yustitia, V. (2020). Keterampilan Berbicara Siswa Sekolah Dasar Melalui Project Based Learning. Primary: Jurnal Pendidikan Guru Sekolah Dasar, 9(5), 672-679. https://doi.org/10.33578/jpfkip.v9i5.80 29

Ghazali, S. A. (2013). Pembelajaran Keterampilan Berbahasa Dengan pendekatan Komunikatif Interaktif. Bandung: PT. Refika Aditama.

Hermansyah, A. K. (2016). Media Pembelajaran Penghantar Berpola Pikir Global Instructional Media As Conductor To Global Mindset. Prosiding Seminar Nasional II Tahun 2016, Kerjasama Prodi Pendidikan Biologi FKIP Dengan Pusat Studi Lingkungan Dan Kependudukan (PSLK) Universitas Muhammadiyah Malang Malang, 26 Maret 2016, 198 212.

Hermansyah, A. K., Suyono, S., \& Hasanah, M. (2017). Desain Pembelajaran Berbicara Untuk Mengenalkan NilaiNilai Moral Kemanusiaan Melalui Bermain Peran. Jurnal Edukasi. https://doi.org/10.19184/jukasi.v4i1.50 89

Hurit, A. A., \& Harmawati, D. (2019). Analisis Kesiapan Guru dalam Mengimplementasikan Kurikulum 2013 di SD Inpres Gudang Arang 
Merauke. Musamus Journal of Primary Education, 116-123. https://doi.org/10.35724/musjpe.v1i2.1 469

Kurniasih, \& Sani. (2015). Model Pembelajaran. Yogyakarta: Kata Pena.

Kurniawan, S. (2016). Pendidikan Karakter: Konsep \& Implementasinya secara terpadu di Lingkungan Keluarga, Sekolah, Perguruan Tinggi, dan Masyarakat. Yogyakarta: Ar-Ruzz Media.

Mahliza, U. D. (2013). Pembelajaran Kooperatif. Yogyakarta: Pustaka Pelajar.

Rahayu, D. P. (2019). Penggunaan Model Pembelajaran Kontekstual untuk Meningkatkan Hasil Belajar Materi Bangun Datar di Kelas III Sekolah Dasar. Musamus Journal of Primary Education, $061-072$. https://doi.org/10.35724/musjpe.v1i2.1 464

Ratnawati, E. (2010). Peningkatan Kemampuan Berbicara Melalui Dongeng Dalam Pembelajaran Bahasa Indonesia Siswa Kelas I Sekolah Dasar Negeri 2 Bendosari Kecamatan Sawit Kabupaten Boyolali Tahun 2010.

Sanjaya, W. (2012). Penelitian Tindakan Kelas Cetakan ke-2. Jakarta: Kencana Prenada Media.

Setiawan, H., \& Tumardi, T. (2019). Pengembangan Instrumen Asesmen Kompetensi pada Ranah Afektif di Sekolah Dasar. Musamus Journal of Primary Education, 2(1), 1-12. https://doi.org/10.35724/musjpe.v2i1.1 944

Sudrajat, A. (2008). Pengertian Pendekatan, Strategi, Metode, Model Pembelajaran. Bandung: Sinar Baru Algensindo.

Sukatmi. (2009). Upaya Meningkatkan Keterampilan Berbicaradengan Media
Gambar (Penelitian Tindakan Kelas pada Siswa Kelas V SD Negeri II Nambangan, Selogiri, Wonogiri).

Sumarsono, A., Syamsudin, S., Hermansyah, A. K., \& Iswahyuni, I. (2018). Model Permainan Target Untuk Meningkatkan Kemampuan Koordinasi Pada Siswa Sekolah Dasar Kelas Atas. Didaktika Tauhidi: Jurnal Pendidikan Guru Sekolah Dasar, 5(2), 135.

https://doi.org/10.30997/dt.v5i2.1305

Susanto. (2016). Teori-teori Belajar Pembelajaran di Sekolah Dasar. Jakarta: Prenada Media Group.

Yunarni, Y., \& Harsiwi, N. E. (2018). Metode Belajar Aktif Untuk Meningkatkan Prestasi Dan Motivasi Belajar Ips Pada Siswa Kelas V SD. Musamus Journal of Primary Education, 049-060. https://doi.org/10.35724/musjpe.v1i1.9 97

Zainudin, A. (2012). Andragogi. Bandung: Angkasa Bandung. 